\title{
Opportunistic vegetation in quarry soil restoration from semiarid South East Spain: pines and spontaneous species.
}

\author{
Lourdes Luna-Ramos ${ }^{1}, \mathrm{R}$ Lazaro $^{2}$, Isabel Miralles ${ }^{3}$, and Albert Sole-Benet ${ }^{1}$ \\ ${ }^{1}$ Consejo Superior de Investigaciones Cientificas \\ ${ }^{2}$ Estacion Experimental de Zonas Aridas \\ ${ }^{3}$ University of Almeria
}

February 14, 2022

\begin{abstract}
The objective was to know the effect of amendments and mulch (pine woodchips) on three planted autochthonous species in two substrates six years after the beginning of the restoration. But because this kind of mulch contained pine cones, pine seedlings appeared after the first year of the restoration; new objectives were added to the initial one: to know if organic amendments influence pine growth among planted vegetation, and if there were competition among planted species, opportunistic species and pines. Essential soil parameters, plant cover and diversity and pine growth were measured and statistically processed with correlation analyses, ANOVA and Detrended Correspondence Analysis. Six years after restoration organic amendments, applied all over the plots contributed significantly to explain the differences on the tested variables. The combined effects of the two substrates and the two organic amendments effectively enhanced soil properties recovery, but they also facilitated the establishment and entry of new species in addition to planted vegetation, driving a differential plant development. The number of pines, as well as their coverage, depended on the interaction between the amendment and the substrate: a) only one amendment favoured the pines and b) the way the amendment works depended on the substrate. Planted vegetation cover and total plant cover from amended plots doubled that of control plots. Results indicate the potential suitability of organic amendments, pine chips mulch and derived opportunistic species for restoring post-mining areas.
\end{abstract}

\section{Introduction}

It is well known that soil restoration is very difficult in arid and semiarid Mediterranean environments. Along with the climatic aridity, precipitation seasonality and its high inter-annual variability, vegetation establishment is quite uncertain because long annual dry periods and short-lasting torrential rainfalls with a high erosive impact. In more humid areas, when available topsoil is stored before mining/quarrying activities and spread on the surface of mined areas after the cease of mining/quarrying activities, soil restoration and revegetation tend to be rather successful. However, the lack of stockpiled soil due to shallow soils in most arid/semiarid Mediterranean areas, adds negative conditions to the restoration. To cope with this problem, organic amendments have been used to create an artificial soil (technosol) to improve the substrate quality thus enhancing the establishment of autochthonous plants (Clemente et al., 2004; Jorba et al., 2008; Asensio et al., 2013). The application of organic amendments in degraded soils improves physicochemical and biological properties of the degraded systems facilitating the entry of other plant species (Maestre and Cortina, 2004). And fast growing spontaneous cover is efficient at soil erosion control, incorporates carbon into substrates, and accelerates pedogenesis (Moreno de las Heras, et al. 2008).

Nevertheless, during the initial and critical stages of plant development, the beneficial properties of planted species may not be enough to control soil erosion and droughts, for which a mulch cover is recommended, especially in slopes (Morgan and Rickson, 1995; Cook et al., 2011). Surface mulches have been shown to play 
an important role on soil properties, hydrology, runoff hydraulics, by increasing water infiltration (Tejedor et al., 2003; Adekalu et al., 2007; Luna et al., 2018) and, in the case of organic mulches, improving soil structure and porosity (Walsh et al., 1996; Mulumba and Lal, 2008), and reducing runoff an erosion (Lal, 1976; Prats et al, 2012; Luna et al, 2018). Other mulch functions include reducing evaporation and buffering changes in soil temperature especially in climatically extreme environments (Robichaud et al., 2013). Despite the statement of Bainbridge (2001) that organic mulches can also pose risks during droughts by limiting infiltration into the soil because light rains can easily evaporate from the mulch itself, other authors reported that globally organic mulches have all the former advantages and also provide organic matter to the substrate (Miller and Seastedt 2009, Eldridge et al 2012). Moreover, organic mulches, and specifically woodchips, significantly enhance microbial activities but not plant cover (Espinosa et al 2020, Fehmi et al 2020).

With the final aim to contribute accelerating the process of ecosystem recovery and to ascertain the specific role of organic amendments and woodchip mulches in the most arid part of southern Europe, an experimental restoration was carried out in a degraded soil from an abandoned quarry in semiarid Sierra de Gádor (Almería, SE Spain). As one of the main goals was to achieve a vegetation cover similar to that present in the surrounding natural areas, the three most abundant native species in the area were planted. Besides the planted species, in the first annual survey, we observed annual and perennial herbaceous plants colonizing the experimental plots to different degrees. In addition to ruderal vegetation, pine seedlings were noticed in the plots related to pine cones from the pine woodchips used as mulch. According Daskalakou and Thanos (1996), preserved cones maintain pine seeds from Pinus halepensis much longer than single pinions released much time before when the cones are still on the tree, which might explain any late pine sprouting from the pine mulch.

In the following years of the experimental restoration, pine seedlings increased in size and they could be distinguished from both the planted and the opportunistic species. In limiting environments with dry conditions, the pine seedlings that grow under the canopy of certain shrubs can benefit from the microclimatic protection as well as from a greater availability of resources in the soil, which usually translate into greater survival (Callaway et al. 2002; Armas and Pugnaire, 2005; Thompson et al., 2017).

In the last decades, ecological restoration projects have highlighted the use of wood plant species because they increase the structure and complexity of ecosystems and can accelerate the regeneration of degraded environments (Vallejo et al., 2009). Despite the slow growth of woody species can be a problem in erosion control and soil formation in the first years of plant development, the Aleppo pine (Pinus halepensis Miller) has been extensively used in afforestation in the Western Mediterranean Basin because is a fast-growing conifer (Quezel, 2000). This species grows on all substrates and within most bioclimates of the Mediterranean region. In such locations, the tree is mainly scattered in lower altitudes, though it also grows in mountainous areas. It is a drought-resistant species, growing well in hot areas exposed to frequent forest fires. Within its distribution area, the tree also provides certain ecosystem services, such as improving water infiltration, preventing soil erosion on dry slopes and serving as windbreak. For these reasons, this tree has been key to several afforestation programs. As a result of these massive reforestations, various studies have been carried out to evaluate these actions. In some cases, pine plantations may have positive effects but the opposite in other cases, with negative effects on both the natural vegetation dynamics and in various ecosystem processes (Maestre and Cortina, 2004).

All these facts added new questions to the initial soil restoration experiment which hypothesis was that the combined effect woodchip mulch and organic amendments could effectively enhance the soil properties recovery and consequently could also facilitate the establishment and entry of new species in addition to planted vegetation. Can there be competition between planted vegetation, ruderal species and pines? We hypothesize that an improvement in soil quality due to restoration treatments, as previously stated in similar experiments in the same area by Luna et al (2016a, 2016b, 2017), can promote competition for nutrients, space and light.

Consequently essential characteristics from both restored substrates and vegetation were monitored 6 years after the establishment of experimental plots and statistical procedures on data measured should respond to 
the raised hypothesis.

\section{Materials and Methods}

\subsection{Site description}

The quarries where the experimental restoration was carried out are at the eastern border of Sierra de Gádor, $36^{\circ} 55^{\prime} 20^{\prime \prime} \mathrm{N}, 2^{\circ} 30^{\prime} 29^{\prime \prime} \mathrm{W}$ (Fig 1), $20 \mathrm{~km} \mathrm{NW}$ of Almeria city, about 370 m a.s.l.

Climate is near the boundary between arid and semiarid, i.e, where the aridity index (P/PET) is slightly below 0.2 (UNESCO, 1977). The data from the Alhama de Almería station (AL003, Junta de Andalucía) show an average annual precipitation, since the hydrological year 2002, of $241 \mathrm{~mm}$, with a minimum annual of $106 \mathrm{~mm}$ and a maximum of $466 \mathrm{~mm}$. The hydrologic years just two years after the start of the experiment were wetter than average (466 $\mathrm{mm}$ and $304 \mathrm{~mm}$ respectively), and the three following years were much drier than average $(167 \mathrm{~mm}, 202 \mathrm{~mm}$ and $165 \mathrm{~mm}$, respectively). Summers are particularly dry and temperatures are quite high (averages $27^{\circ} \mathrm{C}$ in August with mean daily maximum above $35^{\circ} \mathrm{C}$ ).

The natural soils around the quarries are either Calcaric Regosols or Eutric Regosols (IUSS Working Group WRB 2015) which have formed over the lithology of the area (marls and calcareous sandstones) and over mixed slope deposits.

The vegetation around the quarries is essentially an alpha-grass community, clearly dominated by Macrochloa tenacissima (L.) Kunth, with some species of grasses, shrubs or dwarf shrubs such asDactylis hispanica Roth, Rhamnus lycioides L., Maytenus senegalensis Lam., Anthyllis cytisoides L., Anthyllis terniflora (Lag.) Pau, Thymus hyemalis Lange,Artemisia barrelieri Besser, Thymelaea hirsuta(L.) Endl., and Launaea lanifera Pau. Some stands of Pinus halepensis Mill. are found on favorable run-on locations and near a natural spring located not far from the quarried area.

\subsection{Experimental design}

Two types of organic wastes used as organic amendments (compost from urban organic solid wastes and sewage sludge from urban wastewater) were added to two types of substrates (mudstone and topsoil), within the top $15 \mathrm{~cm}$ substrates, and not only into planting holes as done in some large forest restoration plans (e.g., Junta de Andalucía, 1996) and in some recent experiments on mine tailings (e.g., Bindang-Oná et al., 2021).

Moreover, woodchips from silvicultural thinning treatments in a nearby pine forest (Pinus halepensis ) were used as mulch. Three autochthonous species in seedling format, (M. tenacissima, A. terniflora, and A. cytisoides ), were planted. These native plants are keystone elements for ecosystem restoration, providing numerous benefits such as to accelerate secondary succession and ecological recovery.

Six $5 \mathrm{~m} \times 15 \mathrm{~m}$ plots (eighteen $5 \mathrm{~m} \times 5 \mathrm{~m}$ subplots as repetitions) were equally split over two different substrates: a) marl outcrop with $11.6^{\circ}$ slope gradient, and b) topsoil with $15^{\circ}$ slope gradient. The treatments, different technosols, applied equally on both substrates, consisted in two organic amendments (compost from urban organic solid waste and sewage sludge from municipal waste-water treatment plant) plus a control without organic waste in a factorial design $(3 \times 2)$. The stored topsoil had been spread on the surface of 3 plots (9 subplots) just after finishing the mining activities, about 10 years before this experiment. The sewage sludge was added at a rate of $28 \mathrm{~kg} \mathrm{~m}^{-2}$ (total organic $\mathrm{C}=351.5 \mathrm{~g} \mathrm{~kg}^{-1}$ and moisture $=59 \%$ ). The compost was applied at $34 \mathrm{~kg} \mathrm{~m}^{-2}$ (Total organic $\mathrm{C}=196.5 \mathrm{~g} \mathrm{~kg}^{-1}$ and moisture $=40 \%$ ). The added amount was calculated in order the technosols had $2 \%$ of organic matter content. Compost and sewage sludge were incorporated and homogenized into the top $15 \mathrm{~cm}$ of the soil using a mechanical backhoe. The heavy metals contents in both sewage sludge and compost were below the limits established by both the EU Legislation (Official Journal of the European Union, Directives 2018/851 and 2011/92) and the Regional legislation (BOJA, 2015) for contaminated soils.

Subsequent to the application of the organic amendments, woodchip mulch was spread out on the plots with a thickness of $5 \mathrm{~cm}$. Average pine chips measured 1-5 cm wide, 2-10 cm long, and $1 \mathrm{~cm}$ thick (Fig. 1). 
Finally, 75 native plants ( 35 M. tenacissima, 15 A. terniflora and 25 A. cytisoides ) were planted in each experimental plot and some results about these plants were published in Luna et al. (2017, 2018) (Fig. 2).

\subsection{Data collection}

Essential physical and chemical properties of the Technosols were determined just after the beginning of the experiment $\left(1^{\text {st }}\right.$ year $)$ and six years later $\left(6^{\text {th }}\right.$ year $)$ for every experimental plot.

Soil sampling consisted in one composite sample per plot resulting from the homogenization of six soil subsamples taken at random from below mulches, then dried and sieved to $2 \mathrm{~mm}$. Moreover, and as reference soil, in three different points in nearby natural undisturbed soil around the quarry, composite samples (also in the surface layer 0-10 cm) were analyzed. Particle-size analysis was performed with the pipette method. The $\mathrm{pH}$ was determined in an aqueous solution $1 / 2(\mathrm{w} / \mathrm{v})$ in a $\mathrm{pH}$ meter (Crison 2002) and the electrical conductivity (EC) in a $1 / 5(\mathrm{w} / \mathrm{v})$ aqueous solution in a conductivity-meter (Basic 30, Crison, Carpi, Italy). Total calcium carbonate equivalent was measured with Bernard calcimeter. Total Organic Carbon (TOC) by colorimetric determination using the wet oxidation method (Nelson and Sommers, 1996) and total N, using a LECO Truspec C and N analyzer (St. Joseph, MI, USA).

Despite a monthly visual assessment of pines during the first years of the experiment looking at their growth, the inventory was carried out six years since the establishment of the experimental plots (five since the first seedlings appeared). The number of individuals was counted and their height (length of the main stem) and collar diameter $( \pm 0.01 \mathrm{~mm})$ (Fig. 3). Slenderness index was calculated as the ratio of height and collar diameter. As the amount of pine cones introduced with pine chips mulch was not known, the germination rate of pines per plot could not be considered.

We determined the plant cover, including pines, of planted and spontaneous species. The total cover was calculated as the sum of all of them. The methods used were the transect method for pines and the pointintercept frame, a modification of the method used by Floyd and Anderson (1982), with a $20 \mathrm{~cm} \times 20 \mathrm{~cm}$ grid of 400 points arranged in a lattice with $1 \mathrm{~cm}$ grid spacing for the spontaneous vegetation; one grid point count represented $1 \mathrm{~cm}^{2}$ of cover. Percent cover for each subplot was determined by aggregating the data from three $400 \mathrm{~cm}^{2}$ sampling points. The diversity of vegetation species was calculated with the Shannon index $(\mathrm{H})$ using the equation:

$$
H=-\sum_{i=1}^{n} \text { pi ln pi }
$$

where $p i$ is the relative abundance of each vegetal species in the total and $n$ is the number of detected vegetal species. The whole pool of species found was analysed looking for a pattern of species distribution through the plots.

\subsection{Data Analysis}

Factorial ANOVA tested the effects of the two substrates and two organic amendments on soil properties, number, height and slenderness index, and plant cover. The assumption of homogeneity of variance was tested using Levene's test and differences between individual means were evaluated by Tukey's post hoc test at $\mathrm{p}<0.05$. Regression analyses were performed to test for relationships among variables. SPSS v.20 (SPSS, Inc.) was used.

The whole pool of inventoried species was analyzed looking for a pattern of species distribution through the plots by means of Detrended Correspondence Analysis (DCA). In the DCA it was assumed that plots closer to each other in the ordering diagram had a greater floristic similarity. The analyses were carried out using PAST software (Hammer et al., 2009).

\section{RESULTS}

\subsection{Soils}


Table 1 shows essential soil properties of the different Technosols (treatments and reference soil) from the two sites. All soil variables (particle size, $\mathrm{pH}, \mathrm{EC}, \mathrm{CaCO}_{3}$, TOC and TN) show significant degree of heterogeneity despite the analyses were done on composite samples.

Soil texture, not strongly impacted by the soil restoration, was classified as silt loam, and particle size proportions did not change much over time as expected. The natural soil has somewhat higher sand contents (from $37.1 \%$ to $38.9 \%$ ) and lower clay contents (from $10.6 \%$ to $14.5 \%$ ) than the experimental plots (from $26.6 \%$ to $35.4 \%$ and from $7.2 \%$ to $25.6 \%$ respectively).

We observed significant differences $(\mathrm{P}<0.05)$ due to the treatments of organic amendments in all chemical properties after 6 years. Despite this, $\mathrm{pH}$ was quite similar in all plots (Table 1). EC was significantly higher in treatments of compost, reaching $3.8 \mathrm{dS} / \mathrm{m}$ at the first sampling. After 6 years, there was a decrease in $\mathrm{EC}$ on all amended plots up to contents similar to those of the reference soil. $\mathrm{CaCO}_{3}$ equivalent was higher in soils from control plots (without amendments) than in those with amendments and somewhat lower after six years. In all experimental plots, $\mathrm{CaCO}_{3}$ equivalent was higher than in reference soils. Concentrations of TOC and total $\mathrm{N}$ were affected by treatments (Table 1). Higher organic $\mathrm{C}$ contents were observed in compost added treatments compared to those in other Technosols, both at the beginning and after six years. Further, there were also significant differences in $\mathrm{N}$ concentrations among treatments for both sampling periods. The highest $\mathrm{N}$ concentrations were observed in compost. While the highest values for TOC decreased slightly over time, the high concentrations of total $\mathrm{N}$ in compost plots were maintained.

The factorial ANOVA performed with the soil variables on the factorsorganic amendment and topsoil (Table S1) indicate that, primarily, the factor organic amendment contributes significantly to explain the differences for most of the tested variables.

\subsection{Vegetation}

Total plant cover (Table 2) positively and significantly increased from non-amended plots to compostamended plots, being the plots with sewage-sludge in the middle. In all plots (treatments) the topsoil showed plant cover values significantly higher than the marl substrate. However, planted vegetation cover had a different trend, reaching a percentage much higher in the treatment of sewage sludge compared with compost and no amendment.

The cover of spontaneous species (table 2) shows values in the topsoil treatments $(6.6 \%, 16.6 \%$ and $36.6 \%$ ) that doubles those of the marl treatments $(11 \%, 33.3 \%$ and $65 \%)$ and like the total cover, the spontaneous species show a significantly higher percentage with organic amendments, especially with compost.

In the variable number of pines (table 2) we can observe considerable differences depending on the treatment. There are no significant differences between marl substrate and topsoil on plots without organic amendment and sewage sludge. However, compost provoked an opposite behaviour according the initial substrate where applied: on marl substrate, the number of pines is the maximum in all treatments but on the topsoil, the lowest.

The pine cover is related to the number of pines, reaching the highest cover in the treatment of marl with compost amendment and the lowest cover in the topsoil-compost treatment.

In summary, the number of pines, as well as their coverage, depended on the interaction between the amendment and the substrate: a) only one amendment favoured the pines and b) the way the amendment works depended on the substrate.

However, pine height (Fig. 4) is quite similar with the two organic amendments and somewhat different on the two substrates, with larger values in the marl substrate. As expected, height values decrease from compost-amended plots to non-amended plots. Only the organic amendment factor had a significant influence on the height of pines $(P<0.03)$, but there were not many differences in tree height within type of substrate, and only on non-amended plots, pines were slightly higher with topsoil than on the marl substrate. 
In general, the slenderness index in the different plots and under the two substrates (Fig. 5) followed a somewhat similar pattern than pine height. The largest indices for both substrates were found in compostamended plots. Except on the sewage-sludge treatment, the slenderness index values are significantly higher on topsoil than on marl substrate. The lowest indices were found on the marl substrate and non-amended plots.

The relationships between number of pines and TOC per substrate type (compound samples) (Fig. 6) indicate that on the marl substrate the regression is positive $\left(\mathrm{R}^{2}=0.82 ; \mathrm{P}=0.06\right)$, though not significant. However, on the topsoil, the regression is negative and significant $\left(\mathrm{R}^{2}=0.99 ; P<0.02\right)$. Total cover showed somewhat positive and negative relationships with biodiversity (Shannon index) on the two substrates (Fig. 7). This relationship is negative and significant $\left(\mathrm{R}^{2}=0.99, P<0.03\right)$ over topsoil and it is positive and no significant $\left(\mathrm{R}^{2}=0.41 ; P=0.07\right)$ over the marl substrate.

The DCA results in Fig. 8 show that the first axis separates the plots over topsoil and those over marl. Likewise, the two different organic amendments and their control are explained by axis 2: at the lower part, plots without amendments, at the intermediate part, the plots with sewage sludge, and at the upper part, the plots with compost. Pine coverage $(\mathrm{Ph})$ is more associated to the marl than to the topsoil where most of the spontaneous species are found. The spontaneous species are located in the upper left quadrant, associated with amendments and topsoil. The planted species $(M t, A c, A t)$ do not follow the same pattern of preference for soil treatments. Anthyllis species are situated of the left side of ordination axis 1 and are associated with topsoil; however, Macrochloa tenacissima is associated with the marl substrate.

\section{DISCUSSION}

\subsection{Effect of treatments on restored soils (Technosols)}

Natural soils have a somewhat larger sand content than soils (Technosols) from the experimental plots because because the parent material has some influence of a nearby mixed slope deposit containing elements from a calcareous sandstone.

On the opposite, natural soils have a lower $\mathrm{CaCO}_{3}$ equivalent and clay than those from experimental plots. Two facts explain such difference: a) both the marl substrate and the topsoil have higher content of carbonated silty particles from the marl while the natural soil has some influence from the nearby calcareous sandstone containing part of quartz sand grains; b) natural organic matter, has had time enough to contribute by acidification to solubilize part of carbonates as stated by many authors, e.g. Ramnarine et al (2012).

The Technosols from the marl substrate have a larger $\mathrm{CaCO}_{3}$ equivalent content than those from the topsoil which was formed by mixing the marly substrate with stripped topsoil from an area with some calcareous sandstone influence.

It is worth noting that in similar restored soils from the same area (Luna et al, 2017, 2018) the combination compost-woodchips had improved soil structure, higher transmission pores and aggregate stability values, and woodchips alone contributed effectively in reducing surface runoff and soil erosion even with no amendments.

\subsection{Effects of soil treatments on vegetation}

The early establishment of spontaneous species in the restored sites had some impact on both the restored soil and the planted vegetation. These species (e.g., Moricandia foetida, Thymelaea hirsuta, Ulex parviflorus, Artemisia barrilieri, Dittrichia viscosa) quickly colonized disturbed areas as soon as a minimal improvement in edaphic conditions occurred, as reported in similar environments by Soliveres et al. (2012). In some cases, the spontaneous species coverage exceeded that of the native planted species (table 2). For this reason, it was necessary to study the possible effects of the soil treatments on the total plant community. It is well known that changes in edaphic conditions in combination with the competitive characteristics of some plant species can facilitate conditions leading to alternative ecological outcomes among rehabilitated ecosystems (Audet et al., 2013). 
Total plant cover in the treatments without organic amendments was much lower than on the amended soils; however, pine cover percentage was greater than on the substrate where no organic amendment had been applied (table 2). Somehow, woodchip mulch must have improved the soil conditions as has also been reported by other authors (Fristensky and Grismer, 2009; Hueso-González et al., 2016; Yin et al., 2015).

Organic amendments did influence the whole plant community, which means the external nutrient inputs can be important drivers of changes of species diversity. After 6 years, the planted native species reached greater cover with the sludge treatment, despite the fact that the organic matter content in this treatment was considerably lower than that of the compost treatment. Nevertheless there are several factors that were able to affect the response of the planted species. On the one hand, the level and nature of benefit of organic amendments depend on both the quantity (carbon loading) and quality (how easily OM is mineralized, s.l.) of the total OM applied (Bhogal et al., 2018). Higher TOC and N values from compost with regards sewage sludge can be ascribed to the specific chemical composition of these organic amendments (Tejada et al., 2006). Sewage sludge has more labile organic matter and consequently microorganisms favour its initial mineralization and provides readily available nutrients to plants (Hahn and Quideau 2013; Carabassa et al. 2018). On the other hand, the high values of electrical conductivity in the compost treatment could be a handicap for this type of vegetation at the beginning of the experiment (Scotti et al., 2016). However, spontaneous species covered a large percentage the experimental plots where salinity was high, up to $65 \%$ in the treatment with compost over topsoil. These species have an opportunistic strategy, characteristic of severely disturbed but potentially productive habitats (Grime, 1977).

The number of pines and their cover showed a different response to the soil fertility depending on the type of substrate: marl and topsoil (Fig. 6). The results indicate that factors other than organic matter content of the soil could influence, such as competition for light and space (Hess et al., 2019). As expected, inputs of organic material improved pine growth, reaching better height with compost treatments and consequently higher nutrient content. The increase in the slenderness (Fig 5) coefficient under the compost can be interpreted as an indicator of competition for light between woody seedlings and herbaceous vegetation (Eliason \& Allen 1997; Soliveres et al. 2010).

Other authors (Barberá et al., 2005; Ortiz et al., 2012), also found organic amendments as the most effective growth enhancers for pine reforestation in Mediterranean degraded ecosystems. Fuentes et al. (2010) indicated that low to moderate doses of sewage sludge, similar to those used in this research, showed the best combination of seedling survival and growth promoting $P$. halepensis establishment in dry Mediterranean areas. Similar effects had also been reported by Roldán et al. (1996) with 60 and $100 \mathrm{Mg} \mathrm{ha}^{-1}$ of urban solid refuses in a similar environment.

\subsection{Interactions between plant communities}

Biodiversity of plant species was greater in the experimental plots with topsoil because they had a previous seed bank (Golos et al., 2016), and in treatments with organic amendments. However, biodiversity was not proportional to total plant cover. This means that large increases in nutrient inputs do not ensure high plant diversity. Other authors (Moreno de las Heras et al., 2008; Pallavicini et al., 2015) also found a confrontation between high cover of fast-growing spontaneous species and species diversity. This fact may due to competitions or space problems.

The native species planted did not show the colonizing character of the spontaneous vegetation. The establishment of native shrubs depends on various factors in addition to fertile soil, such as the quality of organic matter, salinity, space (Hess et al., 2019; Clemente et al., 2004, Vallejo et al, 2012). That is why they have not achieved the highest cover where there were more nutrients. As seen in the DCA (Fig 8), each of the three planted native species preferred different niches.Anthyllis sp. established better over topsoil, butAnthyllis terniflora was more tolerant to both higher salinity and coexistence with spontaneous species. In contrast, Macrochloa tenacissima preferred the marl substrate with less presence of spontaneous species.

Spontaneous species were also influenced by soil restoration treatments and by total vegetation cover. The number of pines was similar in most of the treatments, except in compost, where there is a large difference 
between the two types of substrate. High vegetation cover can limit the germination of pines that need a lot of light in the early stages of their development (Skordilis and Thanos, 1997; Calama et al., 2017). This is consistent with our results, where the spontaneous species covered almost twice the surface in the topsoil substrate $(65 \%)$ than in the marl $(36.6 \%)$.

Despite it has been mentioned that spontaneous colonizers can prevent native vegetation development due to competition for nutrients, space, light (Holl, 2002) and delay successional advance (Moreno de las Heras et al., 2008), the improvement showed by our amended substrates with regards un-amended ones (Luna et al, 2016a, 2016b, 2017, 2018) indicates that spontaneous vegetation is an essential starting point for a suite of successional mechanisms favoring soil restoration.

The three native planted species are better adapted to local habitats and this fact is key over all in a semi-arid area where conditions are more extreme (Asensio et al., 2013b; Sheoran et al., 2010). However, these three species require a site quality that is not normally achieved in the short term. Many works have reported that vegetation cover is a key parameter for soil stabilization and erosion control in these disturbed areas (Franklin et al., 2012; Bochet et al., 2010). For this reason, earlier colonists that are mostly herbaceous can aid in limiting erosion, as well as favoring successional changes.

In summary, the use of woodchips from pine silvicultural treatments could be used in soil restoration projects as a low-cost mulching technique. Besides protecting against soil erosion and improving the soil water content, they contain cones inducing the establishment of pine seedlings. However, proper pine management will be necessary to avoid the negative impacts reported for dense stands of this Mediterranean pine species if biodiversity maintenance and sustainable ecosystem services are sought (Bellot et al., 2004; Maestre and Cortina, 2004; Moreno-Gutiérrez et al. 2012). An initial restoration with native shrubs on organically amended substrates might be compatible with sparse pines as they both will benefit from two organic matter sources (added organic amendments and organic mulch), and their litter will contribute to enhance soil fertility. The reorientation of woody trees, pines in this case, towards species compositional states that are more similar to native habitats, could be faster using adaptive forest management practices (Onaindia et al. 2013).

The balance between these positive and negative plant interactions will condition the rate and direction of its handling and can therefore be used to influence the adequate development of a degraded system towards the target community as stated by Siles et al. (2008).

\section{CONCLUSIONS}

This study shows that 6 years after soil restoration with two different organic amendments, homogeneously added over the plots, and pine-chips as mulch, together with planting native species, the final plant communities (planted, spontaneous and pines) remain markedly different and enhance soil properties recovery.

Organic amendments favored spontaneous opportunistic species which competed with those planted. Such species can delay succession with regards what would occur if the first step had been only native alpha grass and Anthyllis . Independently of the pace of plant succession, spontaneous plants contribute to erosion control and to pedogenesis.

In this context, this study shows that there are pioneer species which may be used to accelerate secondary succession by facilitating the establishment of such targeted higher-value native species on later successional stages.

The strong interaction between substrates and amendments advises to look closely at which amendments should be used at each site for economic reasons and local availability. But special care should be taken on how they'll be used (characteristics, dose, depth) to avoid unexpected negative results.

Despite we are aware of the need for further studies on other adverse environmental factors such as nutrient limitation, our results indicate the potential suitability of spontaneous species and pine chips mulch for restoration of post-mining areas. 


\section{x. References}

Adekalu, K.O., Olorunfemi, I.A., \& Osunbitan, J.A. (2007). Grass mulching effect on infiltration, surface runoff and soil loss of three agricultural soils in Nigeria. Bioresource Technology, 98, 912-917.

Armas, C., Pugnair, F.I. (2005). Plant interactions govern population dynamics in a semi-arid plant community. $J$ Ecol. , 93, 978-989.

Asensio, V., Covelo, E.F., \& Kandeler, E., (2013a). Soil management of copper mine tailing soils — sludge amendment and tree vegetation could improve biological soil quality. Sci. Total Environ. 456-457, 82-90.

Asensio, V., Vega, F.A., Andrade, M.L., \& Covelo, E.F. (2013b). Technosols made of wastes to improve physico-chemical characteristics of a copper mine soil. Pedosphere, 23, 1-9.

Audet, P., Gravina, A., Glenn, V., Mckenna, P., Vickers, H., Gillespie, M., \& Mulligan, D. (2013). Structural development of vegetation on rehabilitated North Stradbroke Island: Above/belowground feedback may facilitate alternative ecological outcomes. Ecological Processes, 2 20, 1-17.

http://doi.org/10.1186/2192-1709-2-20

Bainbridge, D.A. (2001). Irrigation and surface mulch effects on transplant establishment. Native Plants Journal , 2, 25-29.

Barberá, G.G., Martínez-Fernández, F., Álvarez-Rogel, J., Albadalejo, J., \& Castillo, V. (2005). Shortand intermediate-term effects of site and plant preparation techniques on reforestation of a Mediterranean semiarid ecosystem with Pinus halepensis Mill. New Forests , 29, 177-198.

Bellot, J., Maestre, F.T., Chirino, E., Hernández, N., \& Ortiz de Urbina, J.M. (2004). Afforestation with Pinus halepensis reduces native shrub performance in a Mediterranean semiarid area. Acta Oecologica , 25, 7-15.

Bhogal, A., Nicholson, F.A., Rollett, A., Taylor, M., Litterick, A., Whittingham M.J., \& Williams, J.R. (2018). Improvements in the quality of agricultural soils following organic material additions depend on both the quantity and quality of the materials applied. Front. Sustain. Food Syst. , 19, 113.https://doi.org/10.3389/fsufs.2018.00009.

Bindang-Oná, M., Goberna, M., Navarro-Cano, J.A. (2021). Natural seed limitation and effectiveness of forest plantations to restore semiarid abandoned metal mining areas in SE Spain. Forests , 12(5), 548.https://doi.org/10.3390/f12050548

Bochet, E., García-Fayos, P. \& Tormo, J. (2010). How can we control erosion of roadslopes in semiarid Mediterranean areas? Soil improvement and native plant establishment. Land Degradation and Development , 21, 110-121.

Calama, R., Manso, R., Lucas-Borja, M.E., Espelta, J.M., Piqué, M., Bravo, F., del Peso, C., \& Pados, M. (2017). Natural regeneration in Iberian pines: A review of dynamic processes and proposals for management. Forest Systems , 26(2), 1-20.

Callaway, R.M., Brooker, R.W., Choler, P., Kikvidze, Z., Christopher, J.L., Michalet, R., Paolini, L., Pugnaireq, F.I., Newingham, B., Aschehoug, E.T., Armas, C., Kikodze, D., \& Cook, B.J., 2002. Positive interactions among alpine plants increase with stress. Nature , 417, 844-848.

Carabassa, V., Ortiz, O., \& Alcañiz, J.M. (2018). Sewage sludge as an organic amendment for quarry restoration: effects on soil and vegetation. Land Degradation and Development , 29, 2568- 2574.

Clemente, A,S., Werner C., Máguas, C., Cabral, M.S., Martins-Louçao, M.A., \& Correia, O. (2004). Restoration of a limestone quarry: effect of soil amendments on the establishment of native Mediterranean sclerophyllous shrubs. Restoration Ecology , 12, 20-28. 
Cook, K.L., Wallender, W.W., Bledsoe, C.S., Pasternack, G., \& Upadhyaya, S.K. (2011). Effects of Native Plant Species, Mycorrhizal Inoculum, and Mulch on Restoration of Reservoir Sediment Following Dam Removal, Elwha River, Olympic Peninsula, Washington. Restoration Ecology , 19:251-260.

Daskalakou, E.N. \& Thanos, C.A. (1996). Aleppo pine (Pinus halepensis) postfire regeneration: the role of canopy and soils seed banks.Int. J. Wildland Fire , 6(2), 59-66.

Eliason, S.A. \& Allen, E.B. (1997). Exotic Grass Competition in Suppressing Native Shrubland Reestablishment. Restoration Ecology , 5, 245-255.

Eldridge, J.D., Redente, E.F., \& Paschke, M. (2012). The Use of Seedbed Modifications and Wood Chips to Accelerate Restoration of Well Pad Sites in Western Colorado, U.S.A. Restoration Ecology , 20, 524-531.

Espinosa, N.J., Moore1, D.J.P., Rasmussen, C., Fehmi, J.S., \& Gallery, R-E. (2020). Woodchip and biochar amendments differentially influence microbial responses, but do not enhance plant recovery in disturbed semiarid soils. Restoration Ecology, 28, S381-S392.

Fehmi, J.S., Rasmussen, C., \& Gallery, R.E. (2020). Biochar and woodchip amendments alter restoration outcomes, microbial processes, and soil moisture in a simulated semiarid ecosystem. Restoration Ecolology , 28, S355-S364.https://doi.org/10.1111/rec.131

Floyd, D.A. \& Anderson, J.E. (1982) A new point interception frame for estimating cover of vegetation. Vegetatio , 50, 185-186.

Franklin, J.A., Zipper, C.E., \& Burger, J.A. (2012). Influence of herbaceous ground cover on forest restoration of eastern US coal surface mines. New Forests , 43, 905-924.

Fristensky, A.J., Grismer, M.E. (2009). Evaluation of ultrasonic aggregate stability and rainfall erosion resistance of disturbed and amended soils in the Lake Tahoe Basin, USA. Catena, 79, 93-102.

Fuentes, D., Valdecantos, A., Llovetm J., Cortina, J., \& Vallejo, V.R. (2010). Fine-tuning of sewage sludge application to promote the establishment of Pinus halepensis seedlings. Ecological Engineering , 36, 12131221.

Grime, J.P. (1977). Evidence for the existence of three primary strategies in plants and its relevance to ecological and evolutionary theory. Am Nat, 111, 1169-1194.

Golos, P. J., Dixon, K. W., Erickson, T. E. (2016). Plant recruitment from the soil seed bank depends on topsoil stockpile age, height, and storage history in an arid environment. Restoration Ecology , 24(2), 53-61.https://doi.org/10.1111/rec.12389

Guo, P., Yu, F., Ren, Y., Liu, D., Ouyanf, Z. \& Wang, X. (2018). Response of ruderal species diversity and urban environment: implications for conservation and management. Env. Res. Publ. Health, 15(2), 2832.https://doi.org/10.3390/ijerph15122832

Hahn, A., \& Quideau, S.A. (2013). Long-term effects of organic amendments on the recovery of plant and soil microbial communities following disturbance in the Canadian boreal forest. Plant and Soil , 363, 331-344.

Hammer, Ø., Harper, D.A.T., Ryan, P.D. 2009. Palaeontological Statistics, 92 p. ver. 1.9. Users 501 Manual.https://palaeo-electronica.org/2001_1/past/issue1_01.htm

Hess, M.C.M., Mesléard, F., \& Buisson, E. (2019). Priority effects: emerging principles for invasive plant species management. Ecol. Eng. , 127, 48-57.https://doi.org/10.1016/j.ecoleng.2018.11.011

Holl K.D. (2002). Long-term vegetation recovery on reclaimed coal surface mines in the eastern USA. $J$. Appl. Ecol. , 39, 960-970.

Hueso-González, P., Martínez-Murillo, J.F., Ruiz Sinoga, J.D. (2016). Effects of topsoil treatments on afforestation in a dry-Mediterranean climate (Southern Spain). Solid Earth , 7, 14791489.https://doi.org/10.5194/se-2016-98. 
IUSS Working Group (2014). World Reference Base for Soil Resources. International soil classification system for naming soils and creating legends for soil maps. World Soil Resources Reports $\mathrm{n}^{\mathrm{O}}$ 106, FAO, Rome.

Jorba, M. \& Vallejo, R. (2008). La restauración ecológica de canteras: un caso con aplicación de enmiendas orgánicas y riegos.Ecosistemas , 17, 119-132.

Junta de Andalucía (1997). Proyecto de restauración de la vegetación en 396 ha en Sierra Alhamilla (provincia de Almería). Consejería de Agricultura, Ganadería, Pesca y Desarrollo Sostenible, J.A., Almería.

Kühn, N. (2012). Intentions for the unintentional. Spontaneous Vegetation as the Basis for Innovative Planting Design in Urban Areas.Journal of Landscape Architecture , 1(2), 4653.https://doi.org/10.1080/18626033.2006.9723372

Lal, R. (1976). Soil Erosion Problems on an Alfisol in Western Nigeria and Their Control: Mulching Effect on Runoff and Soil Loss. I.I.T.A. Monograph No. 1. International Institute for Tropical Agriculture, Ibadan, Nigeria.

Luna, L., Pastorelli, R., Bastida, F., Hernández, T., García, C., Miralles, I., Solé-Benet, A. (2016a). The combination of quarry restoration strategies in semiarid climate induces different responses in biochemical and microbiological soil properties. Applied Soil Ecology 107, 33-47.http://dx.doi.org/10.1016/j.apsoil.2016.05.006

Luna, L., Miralles, I,m Andrenelli, M.C., Gispert, M., Pellegrini, S., Vignozzi, N., Solé-Benet, A. (2016b). Restoration techniques affect soil organic carbon, glomalin and aggregate stability in degraded soils of a semiarid Mediterranean region. Catena 143, 256-264.

http://dx.doi.org/10.1016/j.catena.2016.04.013

Luna, L., Vignozzi, N., Miralles, I., \& Solé-Benet, A. (2017). Organic amendments and mulches modify soil porosity and infiltration in semiarid mine soils. Land Degrad. Dev. , 29, 1019-1030.

Luna, L., Miralles, I., Lázaro, R., Contreras, S., \& Solé-Benet, A. (2018). Effect of soil properties and hydrologic characteristics on plants in a restored calcareous quarry under a transitional arid to semiarid climate. Ecohydrology , 11, 1-11.

Maestre, F.T. \& Cortina, J. (2004). Are Pinus halepensis plantations useful as a restoration tool in semiarid Mediterranean areas? Forest Ecology and Management, 198, 303-317.

Miller, E.M. \& Seastedt, T.R. (2009). Impacts of woodchip amendments and soil nutrient availability on understory vegetation establishment following thinning of a ponderosa pine forest. Forest Ecology and Management , 258, 263-272.

Moreno-Gutiérrez, C., Battipaglia, G., Cherubini, P., Saurer, M., Nicolás, E., Contreras, S., \& Querejeta, I. (2012). Stand structure modulates the long-term vulnerability of Pinus halepensis to climatic drought in a semiarid Mediterranean ecosystem. Plant, Cell and Environment, 35, 1026-1039.

Moreno-de Las Heras, M., Nicolau, J.M., \& Espigares, T. (2008). Vegetation succession in reclaimed coal mining slopes in a Mediterranean-dry environment. Ecol Engineer , 34, 168-178.

Morgan, R.P.C. \& Rickson, R.J. (1995). Slope Stabilization and Erosion Control: A Bioengineering Approach. $\mathrm{E}$ and FN Spon, London.

Mulumba, L.N. \& Lal, R. (2008). Mulching effects on selected soil physical properties. Soil and Tillage Research , 98, 106-111.

Nelson, D.W. \& Sommers, L.E. (1982). Total Carbon, Organic Carbon and Organic Matter. In AL Page (ed) Methods of Soil Analysis, part 2, Chemical and Microbiological Properties. pp 539-579.

Onaindia, M., Fernández de Manuel, B., Madariaga, I., \& Rodríguez-Loinaz, G. (2013). Co-benefits and trade-offs between biodiversity, carbon storage and water flow regulation. Forest Ecol. Manag., 289, 1-9. 
Ortiz, O., Ojeda, G., Espelta, J.M., \& Alcañiz, J.M. (2012). Improving substrate fertility to enhance growth and reproductive ability of a Pinus halepensis Mill. afforestation in a restored limestone quarry.New Forests , 43:365-381.

Pallavicini, Y., Alday, J.G., \& Martínez-Ruiz, C. (2015). Factors affecting herbaceous richness and biomass accumulation patterns of reclaimed coal mines Land Degrad. Dev., 26, 211-217.

Prats, S.A., MacDonald, L.H., Monteiro, M., Ferreira, A.J.D., Coelho, C.O.A., \& Keizer, J.J. (2012). Effectiveness of forest residue mulching in reducing post-fire runoff and erosion in a pine and a eucalypt plantation in north-central Portugal. Geoderma, 191, 115-124.

Quezel, P. (2000). Taxonomy and biogeography of Mediterranean pines (Pinus halepensis and P. brutia). In: Ne'eman G, Trabaud L (eds) Ecology, biogeography and managememnt of Pinus halepensis and P. brutia forest ecosysytems in the Mediterranean basin. Backnuys, Leiden, pp 1-12.

Ramnarine, R., Wagner-Riddle, C., Dunfield, K.E., \& Voroney, R.P. (2012). Conteributions of carbonates to soil $\mathrm{CO}_{2}$ emissions. Can. J. Soil Sci., 92, 599-607.

Robichaud, P.R., Ashmun, L.E., Foltz, R.B., Showers, C.G., \& Groenier, J.S. (2013). Production and Aerial Application of Wood Shreds as a Post-Fire Hillslope Erosion Mitigation Treatment. Gen. Tech. Rep. RMRSGTR-307. Fort Collins, CO: U.S. Department of Agriculture, Forest Service, Rocky Mountain Research Station. 31 p.

Roldán, A., Querejeta, I., Albaladejo, J., \& Castillo, V. (1996). Survival and growth of Pinus halepensis Miller seedlings in a semiarid environement after forest soil transfer, terracing and organic amendments. Ann Sci For, 53, 1099-1112.

Scotti, R., Pane, C., Spaccini, R., Palese, A.M., Piccolo, A., Celano, G., \& Zaccardelli, M. (2016): On-farm compost: a useful tool to improve soil quality under intensive farming systems. Applied Soil Ecology , 107, 13-23.http://doi.org/10.1016/j.apsoil.2016.05.004

Sheoran, V., Sheoran, A.S., \& Poonia, P. (2010). Soil Reclamation of Abandoned Mine Land by Revegetation: A Review. International Journal of Soil, Sediment and Water, 3(2), 1-20.

Siles, G., Rey, P. J., Alcántara, J. M., \& Ramírez, J. M. (2008). Assessing the long-term contribution of nurse plants to restoration of Mediterranean forests through Markovian models. Journal of Applied Ecology , 45, 1790-1798.

Skordilis A., Thanos C.A. (1997) Comparative Ecophysiology of Seed Germination Strategies in the Seven Pine Species Naturally Growing in Greece. In: Ellis R.H., Black M., Murdoch A.J., Hong T.D. (eds) Basic and Applied Aspects of Seed Biology. Current Plant Science and Biotechnology in Agriculture, vol 30. Springer, Dordrecht.https://doi.org/10.1007/978-94-011-5716-2_69

Soliveres, S., DeSoto, L., Maestre, F.T. \& Olano, J.M. (2010). Spatio-temporal heterogeneity in abiotic factors modulate multiple ontogenetic shifts between competition and facilitation.Perspectives in Plant Ecology, Evolution and Systematics , 12, 227-234.

Soliveres, S., Monerris, J., Cortina, J. (2012). Irrigation, organic fertilization and species successional stage modulate the response of woody seedlings to herbaceous competition in a semi-arid quarry restoration. Appl. Veg. Sci. , 15, 175-186.

Tejada, M., Garcia, C., Gonzalez, J.L., \& Hernandez, M.T. (2006). Use of organic amendment as a strategy for saline soil remediation: Influence on the physical,chemical, and biological properties of soil.Soil Biol. Biochem. 38, 1413-1421.

Tejedor M, Jiménez C, Díaz F (2003). Volcanic materials as mulches for water conservation. Geoderma $117: 283-295$. 
Thompson, J. A., J. C. Zinnert, and D. R. Young. (2017). Immediate effects of microclimate modification enhance native shrub encroachment. Ecosphere 8(2):e01687. https://doi.org/10.1002/ecs2.168\%.

UNESCO. (1977). Map of the world distribution of arid regions. UNESCO, Paris, $54 \mathrm{p}$.

Vallejo, V. R., Serrasolses, I., Alloza, J.A., Baeza, M.J., Blade, C. Chirino, E., Duguy, B., Fuentes, D., Pausas, J. G., Valdecantos, A., Vilagrosa, A. (2009). Long-term restoration strategies and techniques. In: Cerdá, A., Robichaud, P.R. (eds.). Fire effects on soil and restoration strategies, Science Publishers, Oxford, pp. 373-398.

Vallejo, V. R., Allen, E. B., Aronson, J., Pausas, J. G., Cortina, J., and Gutiérrez, J. R., (2012). Restoration of Mediterranean-type woodlands and shrublands. In: van Andel, J. and Aronson, J., (eds.). Restoration Ecology: The New Frontier . 130-144. Blackwell Publishing Ltd.

Walsh, B.D., Salmins, S., Buszard, D.J., \& MacKenzie, A.F. (1996). Impact of soil management systems on organic dwarf apple orchards and soil aggregate stability, bulk density, temperature and water content.Canadian Journal of Soil Science, 76, 203-209.

Yin, W.,Yu, A.Z., Chai, Q., Hu, F.L., Feng, F. X., \& Gan, Y.T. (2015). Wheat and maize relay-planting with straw covering increases water use efficiency up to $46 \%$. Agronomy for Sustainable Development , 35, 815-825.

https://doi.org/10.1007/s13593-015-0286-1

\section{Hosted file}

Tables and Figures.docx available at https://authorea.com/users/460435/articles/556452opportunistic-vegetation-in-quarry-soil-restoration-from-semiarid-south-east-spainpines-and-spontaneous-species 